\title{
Religion, Polity, and the Natural Environment in the Anthropocene Age
}

Peyman Hekmatpour ${ }^{1}$

University of Oklahoma

\author{
(Working Paper)
}

\begin{abstract}
The Anthropocene age is marked by increased human impacts on the natural environment. As social beings, humans interact with each other, and with their surrounding environments, often through organizations and institutions. Religion and the polity are among the most influential human institutions, and they tend to impact the natural environment in several ways. For instance, several thinkers have claimed that some of the central ideas of the Abrahamic traditions, such as the concept of "Domination of men over the earth," are among the causes of several anthropogenic environmental problems. By contrast, some of the ideas of non-Abrahamic, particularly animistic, religions are found to be associated with environmental conservation and stewardship. The polity can also contribute to environmental problems. The relationship between political organizations and environmental degradation, at any level of analysis from local to global, is well studied and established in the literature. Politicizing the natural environment, however, is not without tradeoffs. Environmentalism, by certain groups of people, is considered as a "stigma," while it is a central concept in the political ideology of another part of the population. This antagonism is harmful to the environmental protection cause. I make the case that religion, or at least a number of religious ideas, can be conducive to the process of depoliticizing the natural environment. In this paper, I strive to draw a theoretical framework to explain how religion and the polity can mutually impact the natural environment.
\end{abstract}

Keywords: Environmental Sociology, Religion, Polity, Human Ecology, Praxis, Late Modernity

${ }^{1}$ Email: peyman.hekmatpour@ou.edu 


\section{Introduction}

Humans' exacerbating impact on the natural environment in the modern era was recognized, by a number of thinkers, as early as in mid-19th century. In 1864, George Perkins Marsh, American diplomat, and philologist, published a book called Man and Nature, discussing how the natural environment can be modified by human action; and in 1873 Italian geologist, Antonio Stoppani referred to "Anthropozoic era" to explain the emergence of a new force, human activities, which is capable of outcompeting other natural forces in power and universality. More recently, the "Anthropocene" label has become more popular (Crutzen 2002, 2006). Fundamental and ever-accelerating changes, primarily caused by human activities, have become increasingly central to how the planet functions (Steffen et al. 2015).

Virtually all human activities are channeled through societal organizations and institutions. Many social thinkers, albeit with different theoretical perspectives, have emphasized the importance of organizations and institutions. Several scholars have highlighted negative ways in which social organizations can impact the environment; for the most part through routinizing humans' environmentally destructive beliefs and activities (Bazerman \& Hoffman 2000; Hoffman \& Ventresca 2002). Religion and the polity are among the oldest, and the most powerful social institutions that can decisively affect the world of nature (Burns et al. 2018). Yet, these institutions are deeply embedded in human culture, a foundation on which the whole human society is built, thus, they should be studied in a collaboration (Burns 2009).

Culture plays a central role in defining the dominant norms and values of a society in every particular era. For instance, the culture of "modernity" highly values ideas such as individualism, scientism, and consumption that can be damaging the natural environment, in several ways (Burns 2009; Burns and LeMoyne 2001; Schnaiberg and Gould 1994; Jorgenson and Burns 2007). Karl Marx argued that human culture, as a superstructure, reflects material 
conditions of the society at any given time (Marx 1977 [1859]). However, William Ogburn (1961 [1932]) contended that there is a time lag in the adaptation of culture to the rapidly changing material conditions. Therefore, we can observe the constant presence of traditional values and ideas in the modern era (Burns 2009).

Processes such as globalization and institutional isomorphism contribute to the emergence of a dominant culture in the world (Hopper 2012; DiMaggio \& Powell 2010; Burns 2009). Nevertheless, this culture of modernity is not entirely new, with its composing elements rooted in some of the oldest social institutions such as religion and the polity. Thus, it is of vital importance to account for this cultural lag when we study the relationship between social institutions and modern problems, including anthropogenic environmental degradation.

There is no consensus over the meaning of religion among scholars (Nongbri 2013). Émile Durkheim (2008 [1912]), in his classic book, The Elementary Forms of Religious Life, defines religion as "a unified system of beliefs and practices.” Sociologist Peter Burger (1967) suggests that religion plays a central role in the processes of building and maintaining a meaningful world for individuals living in a society. Organized world religions (e.g., Judaism, Christianity, Islam, Buddhism, Hinduism, etc.) all started centuries before the beginning of the modern age, yet billions of people in today's world orient their everyday lives around teachings of these religions. Despite its observed general decline in the modern era due to the process of secularization (Berger 1967; Chaves 1994; Chaves 2017; Gorski 2000; Norris and Inglehart 2004; Wallace 1966; Inglehart 1997; Bruce 2002), religion remains a powerful and influential social institution that can impact the natural environment (Cobb 1995; Bube 1988; Burns 2016).

On the other hand, the relationship between the polity and the natural environment is well established in the literature (Dunlap et al. 2001; Dunlap \& McCright 2015). The modern political 
system, although seemingly a new phenomenon, includes institutional forms, values, and ideologies rooted in ancient times (Rahe 1992). The polity has always been affected by religion. In the $19^{\text {th }}$ century, French political scientist and sociologist Alexis de Tocqueville (2003 [1831]) compared American political system to those of European countries and concluded that religion is a significant driver of democracy in America. Robert Bella (1967) argued that the American polity is deeply inspired and affected by several religious ideas, to the extent that it can be considered as a form of religion - the civil religion. The interconnectivity of religion and the polity is not limited to the American society. In fact, there is evidence that this relationship is a global phenomenon (Haynes 2014).

In this paper, I strive to explain how religion and the polity, both separately and in conjunction, can impact the natural environment. I try to draw theoretical lines between these two social institutions and the ways through which they influence individuals' ideas, values, and behavior towards the world of nature. I begin by discussing religions' potential impact on individuals' pro-, or anti-environmental attitudes and behavior, regarding Abrahamic and nonAbrahamic traditions. Then, I shift to the polity and discuss the impacts of governments, NGOs, and IGOs, at different levels of analysis, from local to global. Also, I explain how "environmentalism" has been stigmatized by a significant number of people, while it is a central concept in the ideology of another part of the population. Finally, I make the case that there is a possible interplay between religion and the polity regarding their impacts on the natural environment. I explain how religion is conducive to the process of depoliticizing the natural environment. 


\section{Religion and the Natural Environment}

Religions have influenced human's relationship with the natural world in two ways. Religious teachings have socialized the natural world and framed it in human terms to appease our worldly needs. Moreover, religions have been the "voice of nature to humanity" that remind us of our inevitable connection to the nature (Gottlieb 2003). According to Lynn White (1967), religious teachings such as the "domination of man over the earth," and "the specialness of humankind," among other factors, can be considered as roots of our contemporary environmental issues (Hekmatpour et al. 2017). These beliefs are widely shared by the followers of Abrahamic Religions. However, non-Abrahamic religions (e.g., Hinduism, Taoism, Buddhism, etc.), along with the indigenous faiths of native Americans, are considered to be more environmentally friendly relative to Abrahamic traditions (Hitzhusen 2007; Bond 2016).

A number of studies provide empirical evidence supporting White's argument (e.g., Hand \& Van Liere 1984; Eckberg \& Blocker 1996). For instance, Schultz et. al (2000) suggest that "a literal belief in the Bible leads to a general concern for oneself and other people but not necessarily to a concern for plants and animals." (Schultz et al. 2000: 588). More recently, in New Zealand, researchers found that reading the scripture more frequently can have a direct association with religious fundamentalism, which in return, can lead to lower pro-environmental intentions. (Bulbulia et al. 2016: 278). Moreover, biblical literalism in the United States is shown to be negatively associated with individuals' pro-environmental decisions in their consumption of goods and services provided by the market (Peifer et al. 2016: 661).

Nevertheless, the general argument put by White - that environmental problems of today, partially, are caused by religious beliefs - has been critiqued widely. Critics highlight two major shortcomings in White's argument. First, beliefs such as the superiority of humans on the planet 
are not essentially religious. In other words, other social institutions, such as culture or polity, can also promote these ideas. Second, there is evidence that religious attitudes, beliefs, and behavior are not essentially congruous (see Chaves 2010; Hitzhusen 2007). For example, "What Would Jesus Drive" was the name of the Evangelical Environmental Network's campaign for the reduction of fuel consumption in 2002. Such events are considered as examples of the incongruity between beliefs and actions regarding the environment (Gottlieb 2006).

Religious teachings, in virtually all traditions, are open to numerous ways of interpretation (Hekmatpour and Burns 2019, 2018; Hekmatpour 2018, 2016). A number of scholars draw on the possibility of pro-environmental interpretations of religious teachings and the potential of these interpretations to help create an environmentally friendly ethos (White 1967; Hitzhusen 2007; Burns 2016; Hekmatpour et al. 2017). Saint Francis of Assisi, for example, is considered by Pope Francis (2015) a Christian model of environmental conservativism. Moreover, the mystical interpretation of Islamic teachings, known as Sufism, highly emphasizes notions such as selflessness and unity. Scholars believe that these ideas can potentially promote environmental conservationism within the Islamic context (Hekmatpour et al. 2017).

On the other hand, Eastern traditions, as well as the indigenous American faiths, for the most part, advocate a wholistic relationship between humans and the natural (Bond 2016; Dwivedi 2005; Narayanan 2001). Followers of these religious traditions, in general, adhere to the idea that God, or other higher powers, are immanent in the natural world (James 2003 [1902]). Therefore, scholars have hypothesized that followers of these religious traditions, on average, will show a higher environmental concern, relative to Abrahamic religions (Sarre 1995). Empirical studies attempting to test this hypothesis are scarce (Gifford \& Nilsson 2014). 
Nevertheless, some recent findings suggest that Buddhists, relative to Christians and atheists, are more likely to recycle, and to consume green products, such as organic foods (Minton et al. 2015). Moreover, there is evidence that some Western religious organizations have started to encourage environmental protection among their followers. This has led scholars to discuss the possibility for the emergence of new theologies that are more eco-friendly (Minton et al. 2015; Hitzhusen 2007; Goodchild 2004). For example, the National Association of Evangelicals (NAE) released a statement in 2004 that promotes efforts to address environmental problems such as the global warming (Djupe and Gwiasda 2010).

Throughout history, religion has always been an important provider of morality and ethics for the faithful (Rice 2006; Vitell 2009). Thus, an alternate opinion among advocated by a number of scholars suggests that religiosity, in general and regardless of its context, might be able to promote environmental conservation. According to Gottlieb $(2006,2003)$ religious environmentalism, at least in theory, is possible to achieve within in all religious traditions. Religions can motivate masses of people around the world, offer richer meanings relative to secular movements, and provide a "comprehensive vision of humans and their place in the world." (Szerszynski 2008: 89; Gottlieb 2006). Moreover, a sacred union between humans and the nature supported by religious authority might be able to change people's mindsets about the environment (Gottlieb 2006). Several studies support the hypothesis that religious individuals, on average, are more prone to eco-centric and environmentally friendly beliefs and actions (Minton et al. 2015; Felix and Braunsberger 2016; Martin and Bateman 2014).

Different aspects of religion can contribute to creation of a pro-environmental ethos. For example, attending religious services is found to be positively related to volunteerism for environmental protection (Dilmaghani 2018). However, religion is not the only actor in the 
shaping of perceptions, opinions, and actions regarding the environment. The impact of religion is mediated by cultural values, knowledge, and ideology. Thus, the effect of religion should be considered in a conjunction with other social institutions (Bhuian et al. 2018; Burns et al. 2018; Burns 2009; Gifford and Nilsson 2014; Hitzhusen 2007; Shaiko 1987; Woodrum and Wolkomir 1997; Wolkomir et al. 1997; Guth et al. 1995).

\section{The Polity and the Natural Environment}

Several scholars have investigated the relationship between the polity, as a social institution, and the natural environment at different levels of analysis (Burns et al. 2018; Dunlap et al. 2001; Dunlap and McCright 2015). At the macro-level, several studies have pointed out the importance of nation-states, non-governmental organizations (NGOs), and intergovernmental organizations (IGOs) in environmental protection. For instance, there is evidence that a nationstate's ties and linkages to the "world society," manifested by membership in international environmental NGOs and IGOs, significantly facilitate the process of passing pro-environmental legislations (Hironaka 2002; Frank et al. 2000). Nevertheless, other studies show that lack of enforceable laws, politicizing environmental issues, pro-globalization policies, and foreign direct investment (FDI), tend to negatively impact the natural environment on a global scale (Bager et al. 2015; McCright and Dunlap 2011a; Hirsch 2001; Baek and Koo 2009).

At the meso-level, scholars have contended that despite their rapid growing, both in numbers and in terms of financial turnover, and despite their success in changing citizens' attitudes towards the world of nature, social movements in the form of environmental social organizations (ESMOs) have failed in changing people's behaviors towards the environment to the anticipated extent (Gould et al. 1999; Brulle 2000; Commoner 1991; Burns and LeMoyne 2001; Brulle 2000). This, for the most part, is due to environmental movements' failure in 
prioritizing the environment in political debates (Burns and LeMoyne 2001), and to the emergence of powerful counter-movements in the polity, denying the existence, or the gravity of anthropogenic environmental problems such as climate change (Burns et al. 2018; Aldy 2017; Rosner 2017; Dunlap and McCright 2015).

At the micro-level, political ideologies influence the environment through impacting the public debate and collective actions (Bäckstrand 2003; Frank et al. 2007). Political conservativism, as an ideology, cherishes the ideas of "free market" and "small government." Thus, conservativism is regarded to have a crucial, and generally negative, impact on the environment. (Antonio and Brulle 2011; Dunlap et al. 2001; McCright and Dunlap 2000; Hamilton and Saito 2015, Newman et al. 2016; Choma et al. 2016). Environmental conservation, in most cases, need the governments to constrain the market through regulating businesses (Krieg 1998; Jenkins and Eckert 2000). The government's interference of the market confronts canonical values shared by political conservatives, and consequently, leads conservatives towards less pro-environmental attitudes and behaviors (Jenkins and Eckert 2000; Dunlap and Gale 1974).

The conservative media is intensely funded by a small number of elites who want to turn the public against environmentalism by spreading doubts about the very reality of anthropogenic environmental issues, especially the climate change ( McCright and Dunlap 2003, Jacques et al. 2008, Guber 2013; Hamilton 2011, Coffey and Joseph 2012). Conservative typically question the scientific base of the climate change and openly oppose the efforts to counteract global warming (Jacques et al. 2008; McCright and Dunlap 2000). The anti-environmentalist propaganda, among other factors, significantly impedes the adaptation of environmentally friendly attitudes by conservatives (McCright et al. 2014). 
Scholars have come up with a number of theories to explain why conservatives show significantly lower levels of environmental concern, especially when it comes to certain issues such as the climate change. The idea of "systems justifying tendencies" can partially explain conservatives' reluctance to adapt pro-environmental attitudes (Feygina et al. 2010; McCright and Dunlap 2011b). Preserving the status quo is one of the tenants of political conservativism (Jost et al. 2004) and there is evidence that conservatives are less prone to support environmental conservation because, in most cases, it needs major changes in the traditional ways of living (Feygina et al. 2010). Moreover, the "systems justifying tendencies" reduces conservatives' anxiety, feeling of guilt, discomfort, and uncertainty, when faced by the anthropogenic environmental problems (Jost et al. 2004; Jost and Hunyady 2002).

The concept of the "systems justifying tendencies" builds on a psychological perspective. Nevertheless, one can make the case for a cultural explanation for conservatives' relatively low levels of environmental concern. Each culture has a number of central concepts and values that drive the cognitive process of othering. People tend to categorize others, either as insiders or outsiders, based on their relationship to these central concepts and values (Burns 1999).

Pro-environmentalism is a one of the central values of the politically liberal ideologies (e.g., Peifer et al. 2016; Mostafa 2016; Dalton 2015; Clements et al. 2014; Wardekker et al. 2009; Wapner 1996; Guth et al. 1995; Samdahl and Robertson 1989; Shaiko 1987). Conservatives usually tend to consider liberals as outsiders based on their ideas regarding other issues (e.g., taxation, immigration, abortion, etc.). Therefore, conservatives show less environmental concern, mainly because they want to, at least symbolically, distance themselves more from the liberals and their fundamental values (Hochschild 2016). 
Overall, the natural environment is a highly politicized topic in many contries, to the extent that climate change is considered by a number of scholars as a "tribal" issue, which can divide the public into two opposing camps (Cloud 2016). Many individuals associate “environmentalism" with liberalism (Hutchings 2005; Faulkner 1993). Consequently, this leads to a profound political rift between liberals and conservatives regarding the environment.

Liberals and conservatives not only have politically distinct standpoints about the environmental conservation, but they see the natural environment from two distinct moral perspectives. The liberal-dominated contemporary environmental discourse builds upon the moral belief regarding the society's responsibility of protecting the unfortunate. This is while a reframed rhetoric for environmentalism, one that is based on values such as purity, or the sacredness of the world, can be more attractive for conservatives willing to join the cause of the environmental conservation (Feinberg and Willer 2013).

Moreover, several studies suggest that certain groups of people, particularly conservatives, tend to stigmatize environmentalism (e.g., Marcus et al. 2011; Winter and Koger 2004; Bashir et al. 2013). For instance, a qualitative study shows that a number of people associate environmentalism with environmentalists, labeling people who dedicate their lives and careers to the natural environment, or what they call "outdoorsy stuff," as "hippies" or "tree huggers" (Marcus et al. 2011). Bashir and her associates (2013) contend that social activists, particularly feminists and environmentalists, are viewed as "eccentric" and "militant" by certain groups of individuals. There is evidence that the stigma associated with environmentalism causes a significant number of individuals to resist pro-environmental attitudes and behaviors, and put a barrier on adapting environmentally friendly lifestyles (Winter and Koger 2004; Marcus et al. 2011). 


\section{The Case for an Interplay Between Religion and the Polity}

Religion and the polity can have an interacting effect on the natural environment at virtually every level of analysis. At the macro-level, it appears that world's religious institutions, given their large number of adherents, can have a deceive impact on ways the majority of people in the globe treat the world of nature (Hoffman 2001; Sherkat and Ellison 2007; Tucker and Grim 2001). For instance, the papal encyclical, Laudato Si, particularly with its emphasis on the notion of eco-justice, can reach segments of the world's population (i.e., the poor) that environmentalists, liberal politicians, and scientists have not yet been able to motivate towards pro-environmental collective actions (Hoffman 2015; Kennedy and Santos 2017).

At the meso-level, Burns and LeMoyne (2001) argue that environmental movements can be more effective if they collaborate with other social movements, and frame their rhetoric in moral terms. Religion is the primary source of morality that can offer environmental ethics (Rice 2006; Vitell 2009). There is evidence that "religious-environmental organizations" can give a moral and spiritual dimension to the environmental movement by "stressing human responsibility to care for the earth as a matter of faith" (Smith and Pulver 2009: 169). Therefore, an alliance between environmental and religious movements can impact the natural environment at a higher degree.

Moreover, at the micro-level, it appears that religion can narrow down the political gap in environmental concern between liberals and conservatives. Peifer and his associates (2016) show that as religiosity increases among conservatives, they tend to show higher environmental concern. They attribute this observation to the cognitive process of the "systems justifying tendencies" (Peifer et al. 2016; Jost et al. 2004). They assert that the belief in an active God who constantly intervene the world, lessens the fear of change, and "perhaps conservatives with a 
strong belief in an involved God are less worried about change, alleviating one conservative impediment to environmental consumption.” (Peifer et al. 2016: 684).

Nevertheless, I make the case that there is a cultural explanation for why more religious conservatives have a higher probability of showing environmental concern, relative to less religious conservatives. Environmentalism, as I discussed, is a central concept in liberal political ideologies. Conservatives tend to otherize liberals as outsiders based on critical issues in their ideology, such as taxation, immigration, and abortion, and tend to show less environmental concern in order to distance themselves from environmentalism as the central value in liberal ideologies (Hochschild 2016).

However, for more religious individuals, religion becomes a central value, and other values, including political ideology, become more peripheral. More religious conservatives tend less to otherize liberals, or at least religious liberals with whom they share some values, and thus are more open to embracing pro-environmental attitudes. Put it in Simmelian terms, religion is a transcendental quality which is capable of "reconciliation in and between human beings" (Laermans 2006: 486). Religion can resolve and reconcile "opposites of life" at a higher level of existence (Simmel 1997). Thus, contradictions and antagonisms, such as the liberal versus conservative debate on anthropogenic environmental problems, can be resolved by increased religiosity.

\section{Conclusion}

Religion and the polity are among the oldest and most influential social institutions that tend to direct virtually all human activities. This paper aimed to shed light on how these social institutions, separately and in conjunction, impact the natural environment in the Anthropocene age. Religions, particularly Abrahamic Traditions, are accused of having a potential negative impact on the world of nature. However, as I discussed, this is not always the case. A number of 
ideas in Abrahamic traditions can promote environmental protection (Hekmatpour et al. 2017). On the other hand, religion, for the most part through providing a moral basis for environmental protection, can motivate numerous individuals towards adapting pro-environmental attitudes and behaviors.

Moreover, the polity can impact the natural environment at virtually every level of analysis, from local to global. International environmental NGOs and IGOs tend to have a decisive impact on nation-states, driving them to pass pro-environmental legislation at the local and national level. Nevertheless, politicizing the natural environment, or a number of environmental problems such as climate change, has some tradeoffs. The political divide over climate change between liberals and conservatives and stigmatization of environmentalism are among significant barriers on the way towards embracing environmentally friendly attitudes, particularly for people on the right side of the political spectrum.

However, it appears that religion can narrow down the political gap in pro-environmental attitudes and behaviors, for the most part, through two mechanisms. First, religiosity, in terms of belief in an active supper being, can lessen the fear of change which is more pronounced among conservatives. Second, religiosity, as a Simmelian content, can reconcile contradictions at a higher level of existence, thus mitigates all antagonisms. Put it another way, when religion becomes the central value, other values, including political ideologies, become peripheral, and hence the political divide abates.

There are a number of theoretical, and policy implications associated with the general thesis of this paper. First, social institutions are among the master variables influencing the natural environment (Burns et al. 2018). Therefore, it is of vital importance for environmental research to account for possible interplays between aspects of this master variables. For instance, 
in this paper, I discussed the potential interaction effect of religion and the polity, as two social institutions, on the natural environment at different levels of analysis. One can hypothesize the interaction effects of this sort between virtually all social institutions and between other mater variables influencing the environment, including populations, technology, culture, affluence, and so forth (Burns et al. 2018).

Second, influenced by Lynn White's (1967) argument, the mainstream environmental research has either neglected or underestimated, the potential positive impact of religion for environmental protection (Hitzhusen 2007). There is empirical evidence that religion, in fact, promotes environmentally friendly attitudes and behaviors, either directly (Felix and Braunsberger 2016; Minton et al. 2015; Martin and Bateman 2014) or through interacting with other social institutions (Bhuian et al. 2018; Peifer et al. 2016; Gifford and Nilsson 2014). Thus, it appears more than necessary for environmental researchers to reframe theories of human interaction with the natural environment, accounting for the possible, and significant impact of religion.

Finally, as I discussed, politicizing and stigmatizing environmentalism only exacerbate the divide over the natural environment. Religion, in terms of religious ideas and institutions, can be used to overcome the antagonism on anthropogenic environmental degradation. On the other hand, as Burns and LeMoyne (2001) argue, a reframing of rhetoric is needed if environmental movements want to be more effective in the course of environmental protection. Incorporating religious concepts and ideas into the rhetoric of environmental movements can lessen the stigma associated with environmentalist, and along with collaboration with religious institutions, can motivate a larger and more diverse population towards adapting environmentally friendly 
behaviors. This can be the first step towards reaching a collective environmental conscious which is indispensable if human beings want to survive the Anthropocene. 


\section{References}

Aldy, Joseph E. 2017. "Real world headwinds for Trump climate change policy." Bulletin of the Atomic Scientists 73(6): 376-381.

Antonio, Robert J., and Robert J. Brulle. 2011. "The unbearable lightness of politics: Climate change denial and political polarization." The Sociological Quarterly 52(2): 195-202.

Bäckstrand, Karin. 2003. "Civic science for sustainability: reframing the role of experts, policymakers and citizens in environmental governance." Global Environmental Politics 3(4): 24-41.

Baek, Jungho, and Won W. Koo. 2009. "A dynamic approach to the FDI-environment nexus: the case of China and India." East Asian Economic Review 13(2): 78-160.

Bager, Alex, Carlos E. Borghi, and Helio Secco. 2015. "The influence of economics, politics, and environment on road ecology in South America." in Van der Ree, Rodney, Daniel J. Smith, and Clara Grilo (eds.), Handbook of road ecology. Chichester, West Sussex: Wiley Blackwell.

Bashir, Nadia Y., Penelope Lockwood, Alison L. Chasteen, Daniel Nadolny, and Indra Noyes. 2013. "The ironic impact of activists: Negative stereotypes reduce social change influence.” European Journal of Social Psychology 43(7): 614-626.

Bazerman, Max H., and Andrew John Hoffman. 2000. "Sources of environmentally destructive behavior: Individual, organizational and institutional perspectives." Research in Organizational Behavior 21: 39-79.

Bhuian, Shahid Nakib, Sujeet Kumar Sharma, Irfan Butt, and Zafar U. Ahmed. 2018. "Antecedents and pro-environmental consumer behavior (PECB): the moderating role of religiosity." Journal of Consumer Marketing 35(3): 287-299.

Bond, Erik. 2016. "Native Voices, The Indigenous View of Environmentalism: Tribe, Nature, and Kinship.” in Caniglia, Beth S., Thomas J. Burns, Rachel M. Gurney, and Erik L. Bond (eds.), Rise of Environmental Consciousness: Voices in pursuit of a sustainable planet. San Diego, CA: Cognella.

Bube, Paul Custodio. 1988. Ethics in John Cobb's Process Theology. Atlanta, GA: Scholars Press.

Bulbulia, Joseph, Geoffrey Troughton, Lara M. Greaves, Taciano L. Milfont, and Chris G. Sibley. 2016. "To burn or to save? The opposing functions of reading scripture on environmental intentions." Religion, Brain \& Behavior 6(4): 278-289.

Burns, Thomas Jerome. 1999. "Rhetoric as a framework for analyzing cultural constraint and change." Current Perspectives in Social Theory 19: 165-186.

Burns, Thomas J. 2009. "Culture and the Natural Environment." in Alpina Begossi and Priscila F. Lopes (eds.), Current Trends in Human Ecology. Newcastle upon Tyne, U.K.: Cambridge Scholars Press.

Burns, Thomas J. 2016. "Reconsidering Scripture in Late Industrial Society: Religious Traditions and the Natural Environment." in Caniglia, Beth S., Thomas J. Burns, Rachel M. Gurney, and Erik L. Bond (eds.), Rise of Environmental Consciousness: Voices in pursuit of a sustainable planet. San Diego, CA: Cognella.

Burns, Thomas J., and Terri LeMoyne. 2001. "How environmental movements can be more effective: Prioritizing environmental themes in political discourse." Human Ecology Review 8(1): 26-38. 
Burns, Thomas J., Peyman Hekmatpour, and Kristen C. Speer. 2018. "Human Interaction with the Natural Environment: The POETICAS Model as a Framework for Understanding and Praxis in Late Modernity." International Journal of environment and climate change 8(3): 234-268.

Chaves, Mark. 2010. "SSSR presidential address rain dances in the dry season: Overcoming the religious congruence fallacy." Journal for the Scientific Study of Religion 49(1): 1-14.

Choma, Becky L., Yaniv Hanoch, and Shannon Currie. 2016. "Attitudes toward hydraulic fracturing: The opposing forces of political conservatism and basic knowledge about fracking." Global Environmental Change 38: 108-117.

Clements, John M., Aaron M. McCright, and Chenyang Xiao. 2014. "Green Christians? An empirical examination of environmental concern within the US general public." Organization \& Environment 27(1): 85-102.

Cloud, Doug. 2016. "Communicating Climate Change to Religious and Conservative Audiences." Reflections 16: 57-73.

Cobb, John B. 1995. Is It Too Late? The Theology of Ecology. Denton, TX: Environmental Ethics Books.

Coffey, Daniel J., and Patricia Hallam Joseph. 2013. "A polarized environment: The effect of partisanship and ideological values on individual recycling and conservation behavior." American Behavioral Scientist 57(1): 116-139.

Congleton, Roger D. 1992. "Political institutions and pollution control." The review of economics and statistics : 412-421.

Crutzen, Paul J. 2002. “Geology of mankind.” Nature 415(6867): 23.

Crutzen, Paul J. 2006. “The "anthropocene.” In Ehlers, Eckart and Thomas Krafft. Earth System Science in the Anthropocene: Emerging Issues and Problems. Berlin: Springer.

Dalton, Russell J. 2015. "Waxing or waning? The changing patterns of environmental activism." Environmental Politics 24(4): 530-552.

Dilmaghani, Maryam. 2018. "Which is greener: secularity or religiosity? Environmental philanthropy along religiosity spectrum." Environmental Economics and Policy Studies 20(2): 477-502.

Djupe, Paul A., and Gregory W. Gwiasda. 2010. "Evangelizing the environment: Decision process effects in political persuasion." Journal for the Scientific Study of Religion 49(1): 73-86.

Dunlap, Riley E., and Richard P. Gale. 1974. "Party membership and environmental politics: A legislative roll-call analysis.” Social Science Quarterly 55 (3): 670-690.

Dunlap, Riley E., Chenyang Xiao, and Aaron M. McCright. 2001. "Politics and environment in America: Partisan and ideological cleavages in public support for environmentalism." Environmental politics 10(4): 23-48.

Dunlap, Riley E, Aaron M. McCright. 2015. "Challenging climate change: The denial countermovement". In Dunlap, Riley and Robert J. Brulle (eds.), Climate Change and Society: Sociological Perspectives. NY: Oxford University Press.

Durkheim, Émile. 2008. The Elementary Forms of Religious Life. Oxford: Oxford University Press.

Dwivedi, O. P. 2005. "Satyagraha for conservation: A Hindu view." in Pojman, Louis P. (ed) Environmental Ethics: Readings in Theory and Application. Belmont. CA: Wadsworth/Thomson. 
Faulkner, Robert K. 1993. "The United States: Liberals, Conservatives, and the Challenge of Liberation.” Political Studies 41(1): 107-132.

Eckberg, Douglas Lee, and T. Jean Blocker. 1996. "Christianity, environmentalism, and the theoretical problem of fundamentalism.” Journal for the Scientific Study of Religion 35(4): 343-355.

Feinberg, Matthew, and Robb Willer. 2013. "The moral roots of environmental attitudes." Psychological Science 24(1): 56-62.

Felix, Reto, Chris Hinsch, Philipp A. Rauschnabel, and Bodo B. Schlegelmilch. 2018. "Religiousness and environmental concern: A multilevel and multi-country analysis of the role of life satisfaction and indulgence.” Journal of Business Research 91: 304-312.

Francis, Pope. 2015. Laudato si: On care for our common home. Vatican City: Libreria Editrice Vaticana.

Frank, David John, Ann Hironaka, and Evan Schofer. 2000. "The nation-state and the natural environment over the twentieth century." American Sociological Review 65(1): 96-116.

Frank, David John, Wesley Longhofer, and Evan Schofer. 2007. "World society, NGOs and environmental policy reform in Asia." International Journal of Comparative Sociology 48(4): 275-295.

Feygina, Irina, John T. Jost, and Rachel E. Goldsmith. 2010. "System justification, the denial of global warming, and the possibility of "system-sanctioned change"." Personality and social psychology bulletin 36(3): 326-338.

Greeley, Andrew. "Religion and attitudes toward the environment." Journal for the Scientific Study of Religion 32(1): 19-28.

Gifford, Robert, and Andreas Nilsson. 2014. "Personal and social factors that influence proenvironmental concern and behaviour: A review." International Journal of Psychology 49(3): 141-157.

Gottlieb, Roger S. 2003. This sacred earth: Religion, nature, environment. New York: Routledge.

Gottlieb, Roger S. 2006. A Greener Faith: Religious Environmentalism and Our Planet's Future. Oxford: Oxford University Press.

Guber, Deborah Lynn. 2013. “A cooling climate for change? Party polarization and the politics of global warming." American Behavioral Scientist 57(1): 93-115.

Guth, James L., John C. Green, Lyman A. Kellstedt, and Corwin E. Smidt. 1995. "Faith and the environment: Religious beliefs and attitudes on environmental policy." American Journal of Political Science 39(2): 364-382.

Hamilton, Lawrence C. 2011. "Education, politics and opinions about climate change evidence for interaction effects." Climatic Change 104(2): 231-242.

Hamilton, Lawrence C., and Kei Saito. 2015. "A four-party view of US environmental concern." Environmental Politics 24(2): 212-227.

Hand, Carl M., and Kent D. Van Liere. 1984. "Religion, mastery-over-nature, and environmental concern.” Social Forces 63(2): 555-570.

Haynes, Jeff. 2014. Religion in global politics. New York: Routledge.

Hekmatpour, Peyman. 2016. "Shia Islam and Religious Forbearance among Students in Iran: A Qualitative Study Using the Concept of Social Norms." International Journal of Humanities and Social Science Invention 5(12): 65-73. 
Hekmatpour, Peyman. 2018. "What do we know about the Islamic Radicalism: A meta-analysis of academic publications." Conference Paper Presented at the $113^{\text {th }}$ Annual Meeting of the American Sociological Association, Philadelphia, PA. available at: https://bit.ly/3bk5vCg

Hekmatpour, Peyman, and Thomas J. Burns. 2018. "Radicalism and Enantiodromia: A Trialectic of Modernity, Post-modernity, and Anti-modernity in the Islamic World." Conference Paper Presented at the $113^{\text {th }}$ Annual Meeting of the American Sociological Association, Philadelphia, PA. available at: https://bit.ly/2LiBisQ

Hekmatpour, Peyman, and Thomas J. Burns. 2019. "Perception of Western governments' hostility to Islam among European Muslims before and after ISIS: the important roles of residential segregation and education" British Journal of Sociology 70(5): 2133-2165.

Hekmatpour, Peyman, Thomas J. Burns, and Tom W. Boyd. 2017. "Is Islam Pro-or AntiEnvironmental? Interpretations and Implications." Journal of Asian Research 1(1): 92110.

Hironaka, Ann. 2002. "The globalization of environmental protection: The case of environmental impact assessment." International Journal of Comparative Sociology 43(1): 65-78.

Hirsch, Philip. 2001. "Globalisation, regionalisation and local voices: The Asian Development Bank and rescaled politics of environment in the Mekong region." Singapore Journal of Tropical Geography 22(3): 237-251.

Hitzhusen, Gregory E. 2007. "Judeo-Christian theology and the environment: moving beyond scepticism to new sources for environmental education in the United States." Environmental Education Research 13(1): 55-74.

Hochschild, Arlie R. 2016. Strangers in their own land: Anger and mourning on the American right. New York: The New Press.

Hoffman, Andrew J. 2001. "Linking organizational and field-level analyses: The diffusion of corporate environmental practice." Organization \& Environment 14(2): 133-156.

Hoffman, Andrew J. 2015. "Laudato Si' and the role of religion in shaping humanity's response to climate change," Solutions 6(5): 40-47.

Hoffman, Andrew J. and Marc J. Ventresca. 2002. Organizations, Policy and the Natural Environment: Institutional and Strategic Perspectives. Stanford, CA: Stanford University Press.

Hutchings, Kevin. 2005. “Don't Call Me a Tree Hugger!: Sticks, Stones, and Stereotypes in Ecocriticism.” Interdisciplinary Literary Studies 7(1): 5-26.

Inglehart, Ronald. 1997. Modernization and Postmodernization: Cultural, Economic, and Political Change in 43 Societies. Princeton: Princeton University Press.

Jacques, Peter J., Riley E. Dunlap, and Mark Freeman. 2008. "The organisation of denial: Conservative think tanks and environmental scepticism." Environmental politics 17(3): 349-385.

James, William. 2003 [1902]. The varieties of religious experience: A study in human nature. New York: Routledge.

Jenkins, J. Craig, and Craig M. Eckert. 2000. "The right turn in economic policy: Business elites and the new conservative economics." Sociological Forum 15(2): 307-338.

Jenkins, Willis, and Christopher Key Chapple. 2011. "Religion and environment." Annual Review of Environment and Resources 36: 441-463.

Jost, John, and Orsolya Hunyady. 2003. "The psychology of system justification and the palliative function of ideology." European review of social psychology 13(1): 111-153. 
Jost, John T., Mahzarin R. Banaji, and Brian A. Nosek. 2004. "A decade of system justification theory: Accumulated evidence of conscious and unconscious bolstering of the status quo." Political psychology 25(6): 881-919.

Kennedy, Ann-Marie, and Nicholas JC Santos. 2017. “The papal encyclical Laudato si': A focus on sustainability attentive to the poor." The Journal of Management for Global Sustainability 5(1): 109-134.

Krieg, Eric J. 1998. "The two faces of toxic waste: trends in the spread of environmental hazards." Sociological Forum 13(1): 3-20.

Laermans, Rudi. 2006. "The ambivalence of religiosity and religion: a reading of Georg Simmel." Social Compass 53(4): 479-489.

Marcus, Benjamin J., Allen M. Omoto, and Patricia L. Winter. 2011. "Environmentalism and community: Connections and implications for social action." Ecopsychology 3(1): 11-24.

Martin, William C., and Connie R. Bateman. 2014. "Consumer religious commitment's influence on ecocentric attitudes and behavior.” Journal of Business Research 67, no. 2 (2014): 511.

Marx, Karl. 1977 [1859]. A Contribution to the Critique of Political Economy. Moscow: Progress Publishers.

McCright, Aaron M., and Riley E. Dunlap. 2000. "Challenging global warming as a social problem: An analysis of the conservative movement's counter-claims." Social problems 47(4): 499-522.

McCright, Aaron M., and Riley E. Dunlap. 2003. "Defeating Kyoto: The conservative movement's impact on US climate change policy." Social problems 50(3): 348-373.

McCright, Aaron M., and Riley E. Dunlap. 2011a. "The politicization of climate change and polarization in the American public's views of global warming, 2001-2010." The Sociological Quarterly 52(2): 155-194.

McCright, Aaron M., and Riley E. Dunlap. 2011b. "Cool dudes: The denial of climate change among conservative white males in the United States." Global environmental change 21(4): 1163-1172.

McCright, Aaron M., Chenyang Xiao, and Riley E. Dunlap. 2014. "Political polarization on support for government spending on environmental protection in the USA, 1974-2012." Social Science Research 48: 251-260.

Minton, Elizabeth A., Lynn R. Kahle, and Chung-Hyun Kim. 2015. "Religion and motives for sustainable behaviors: A cross-cultural comparison and contrast." Journal of Business Research 68(9): 1937-1944.

Mostafa, Mohamed M. 2016. "Post-materialism, religiosity, political orientation, locus of control and concern for global warming: a multilevel analysis across 40 nations." Social Indicators Research 128(3): 1273-1298.

Narayanan, Vasudha. 2001. "Water, wood, and wisdom: Ecological perspectives from the Hindu traditions.” Daedalus 130(4): 179-206.

Newman, Brian, James L. Guth, William Cole, Chris Doran, and Edward J. Larson. 2016.

"Religion and environmental politics in the US house of representatives." Environmental Politics 25(2): 289-314.

Norris, Pippa, and Ronald Inglehart. 2004. Sacred and Secular: Religion and Politics Worldwide. New York: Cambridge University Press. 
Ogburn, William. 1961 (1932). "The hypothesis of cultural lag”. In Parsons, Talcott., Edward Shils, Kaspar D. Naegele and Jesse R. Pitts. (eds.), Theories of Society: foundations of modern sociological theory. New York: Free Press.

Peifer, Jared L., Simranjit Khalsa, and Elaine Howard Ecklund. 2016. "Political conservatism, religion, and environmental consumption in the United States." Environmental Politics 25(4): 661-689.

Rahe, Paul A. 1992. Republics, Ancient and Modern: Classical Republicanism and the American Revolution. Chapel Hill: University of North Carolina Press.

Rice, Gillian. 2006. "Pro-environmental behavior in Egypt: Is there a role for Islamic environmental ethics?." Journal of business ethics 65(4): 373-390.

Rosner, David. "Health, Climate Change, and the Descent of Science-Based Policy." The Milbank Quarterly 95(1):36-39.

Samdahl, Diane M., and Robert Robertson. 1989. "Social determinants of environmental concern: Specification and test of the model." Environment and behavior 21(1): 57-81.

Sarre, Philip. 1995. "Towards global environmental values: Lessons from western and eastern experience." Environmental Values 4(2): 115-127.

Schultz, P. Wesley, Lynnette Zelezny, and Nancy J. Dalrymple. 2000. "A multinational perspective on the relation between Judeo-Christian religious beliefs and attitudes of environmental concern." Environment and Behavior 32(4): 576-591.

Shaiko, Ronald G. 1987. "Religion, politics, and environmental concern: A powerful mix of passions.” Social Science Quarterly 68(2): 244.

Sherkat, Darren E., and Christopher G. Ellison. 2007. "Structuring the religion-environment connection: Identifying religious influences on environmental concern and activism." Journal for the Scientific Study of Religion 46(1): 71-85.

Simmel, Georg. 1997. Essays on Religion. New Haven: Yale University Press.

Smith, Angela M., and Simone Pulver. 2009. "Ethics-based environmentalism in practice: Religious-environmental organizations in the United States." Worldviews: Global Religions, Culture, and Ecology 13(2): 145-179.

Steffen, Will, Wendy Broadgate, Lisa Deutsch, Owen Gaffney, and Cornelia Ludwig. 2015. "The trajectory of the Anthropocene: the great acceleration." The Anthropocene Review 2(1): 81-98.

Szerszynski, Bronislaw. 2008. "A Greener Faith: Religious Environmentalism and Our Planet's Future by Roger Gottlieb.” Book Review. Organization \& Environment 21(1): 89-91

Tocqueville, Alexis. 2003 [1831]. Democracy in America. Washington, DC.: Regnery Publishing.

Tucker, Mary Evelyn, and John A. Grim. 2001. "Introduction: The emerging alliance of world religions and ecology." Daedalus 130(4): 1-22.

Vitell, Scott J. 2009. "The role of religiosity in business and consumer ethics: A review of the literature." Journal of Business Ethics 90(2): 155-167.

Wapner, Paul Kevin. 1996. Environmental activism and world civic politics. Albany: Suny Press.

Wardekker, J. Arjan, Arthur C. Petersen, and Jeroen P. van Der Sluijs. 2009. "Ethics and public perception of climate change: Exploring the Christian voices in the US public debate." Global Environmental Change 19(4): 512-521. 
White, Lynn. 1967. “The Historical Roots of Our Ecologic Crisis.” Science 155(3767): 12031207.

Winter, Deborah Du Nann, and Susan Koger. 2004. The Psychology of Environmental Problems: Psychology for Sustainability. Mahwah, NJ: Lawrence Erlbaum Associates

Woodrum, Eric, and Michelle J. Wolkomir. 1997. "Religious effects on environmentalism." Sociological Spectrum: Mid-South Sociological Association 17(2): 223-234.

Wolkomir, Michelle, Michael Futreal, Eric Woodrum, and Thomas Hoban. 1997. "Substantive religious belief and environmentalism." Social Science Quarterly 78(1): 96-108. 